\title{
Vocational interests and professional choice self-efficacy of adolescents and youngsters
}

\author{
Interesses profissionais e autoeficácia para \\ escolha em adolescentes e jovens
}

\author{
Camélia Santina MURGO1 (iD) 0000-0003-3932-7580 \\ Leonardo de Oliveira BARROS ${ }^{2}$ iD 0000-0002-8406-0515 \\ Bárbara Cristina Soares SENA ${ }^{3}$ iD 0000-0002-0164-7004
}

\begin{abstract}
This study aimed to analyze the relationships between self-efficacy beliefs and professional interests of 613 adolescents and young people from the interior of the State of São Paulo, Brazil, aged 15-19 years $(M=16.65 ; S D=0.75)$ of which 350 were female, coming from public (84\%) and private (15.8\%) schools. The instruments used were the Self-Directed Search Career Explorer and the Self-Efficacy Scale for Professional Choice. Women had higher mean in the Social type and men in the Realistic, Entrepreneurial and Conventional types. In self-efficacy for professional choice, students from private schools revealed higher mean than students from public schools. The general level of self-efficacy was explained by investigative, artistic, social interests and type of school. The results also indicate the importance of analyzing the differences found in gender interests. In addition, the study can contribute to the work of counselors regarding the insertion of discussions that help adolescents to understand the influences of interests and self-efficacy in the construction of professional projects, besides bringing more systematic data on the articulation between such constructs.
\end{abstract}

Keywords: Career choice; Psychometrics; Self efficacy; Vocational guidance.

\section{Resumo}

Este estudo objetivou analisar as relações entre as crenças de autoeficácia e os interesses profissionais de 613 adolescentes e jovens do interior do Estado de São Paulo com idades entre 15 e 19 anos $(M=16,65 ; D P=0,75)$, sendo 350 do sexo

\section{$\because \mathrm{V}$}

1 Universidade do Oeste Paulista, Centro de Ciências Humanas, Programa de Pós-Graduação em Educação. Rod. Raposo Tavares, s/n., km 572, Jd. Satélite, 19063-005, Presidente Prudente, SP, Brasil. Correspondence to: C.S. MURGO. E-mail: <camelia@unoeste.br>.

2 Universidade Federal da Bahia, Instituto de Psicologia, Faculdade de Psicologia. Salvador, BA, Brasil.

3 Universidade Federal de São Carlos, Centro de Educação e Ciências Humanas, Programa de Pós-Graduação em Psicologia. São Carlos, SP, Brasil.

$\nabla \nabla \nabla$

How to cite this article

Murgo, C. S., Barros, L. O., \& Sena, B. C. S. (2020). Vocational interests and professional choice self-efficacy of adolescents and youngsters. Estudos de Psicologia (Campinas), 37, e190013. http://dx.doi.org/10.1590/1982-0275202037e190013 
feminino, oriundos de escolas públicas (84\%) e particulares (15,8\%). Como instrumentos foram utilizados o Self-Directed Search Career Explorer e a Escala de Autoeficácia para Escolha Profissional. As mulheres apresentaram maiores médias no tipo Social, e os homens nos tipos Realista, Empreendedor e Convencional. Quanto à autoeficácia para escolha profissional, alunos de escolas particulares demonstraram maiores médias em relação aos estudantes de escolas públicas. O nível geral de autoeficácia foi explicado por interesses investigativos, artísticos, sociais e pelo tipo de escola. Os resultados indicam a importância de se analisar as diferenças encontradas nos interesses no tocante ao gênero. Além disso, o estudo pode contribuir com o trabalho dos orientadores quanto à inserção de discussões que auxiliem os adolescentes a compreender as influências dos interesses e da autoeficácia na construção de projetos profissionais, assim como trazer dados mais sistematizados sobre a articulação entre esses construtos.

Palavras-chave: Escolha da profissão; Psicometria; Autoeficácia; Orientação vocacional.

The Social Cognitive Career Development Theory (TSCDC, Teoria Social Cognitiva de Desenvolvimento de Carreira) (Lent, Brown, \& Hackett, 1994), based on the Social Cognitive Theory (Bandura, 1997) is one of the explanatory models for professional development. This dimension contains three interrelated steps concerning career decisions, which are: the formation of interests; academic and career choice; and performance and persistence in educational and occupational pursuits. In addition to these steps, socio-cognitive mechanisms that affect the professional choice process are also proposed, and those considered the most significant are: self-efficacy beliefs and expected outcome (Lent et al., 1994).

Self-efficacy is understood as an individual's beliefs in his/her ability to successfully plan and execute a given action (Bandura, 1997). These beliefs can help explain the initiative, perseverance and success that can be achieved in the course of activities (Pajares \& Olaz, 2008). It should be emphasized that self-efficacy is considered a self-assessment in relation to one's own ability and does not necessarily mean having or not a certain skill (Bandura, 1997). Thus, performance of an action also depends on the person's actual competence and also on incentives and opportunities to perform that action (Ambiel \& Noronha, 2012).

Thus, self-efficacy and its sources are important for reflecting on professional choice, since they refer to motivational aspects involved in the decision-making process (Lent, Ireland, Penn, Morris, \& Sappington, 2017). As important as the real ability in a certain area, a positive belief in the personal ability to act in this area is essential, since this confidence can increase the chance of involvement in activities (Nunes \& Noronha, 2011), establishing relationships with the work environment (Ambiel \& Noronha, 2014), as well as creating goals and developing professional interests (Lent, 2016; Prisco, Martins, \& Nunes, 2013).

In this regard, Whiston, Mitts, and Wright (2017) carried out a meta-analysis on career choice interventions in which 57 studies were included in order to verify the variable with the greatest impact on career interventions. Among the different variables (vocational identity, barriers, environmental support, expected outcome, etc.), the studies that addressed self-efficacy for career decision-making were the ones that indicated the largest effect sizes $(d=0.452)$. Thus, self-efficacy for career decision was identified by the authors as a fundamental aspect to be addressed in interventions, generating positive results for the individuals.

With regard to the relationships between self-efficacy and other variables in the selection process, the relationship established with professional interests stands out; they are defined as patterns of tastes, dislikes and indifference regarding activities and occupations associated with a specific professional (Lent at al., 1994). It is understood that self-efficacy and expected outcome precede the construction of interests, operating directly upon them (Choi et al., 2011). Positive perceptions of self-efficacy tend to foster greater commitment towards the tasks of interest, while negative perceptions of self-efficacy can result in avoidance of activities and exclusion of professionals (Nunes \& Noronha, 2011).

It is important to emphasize that, although there is a relationship between self-efficacy and professional interests, they differ conceptually and empirically (Lent, Hackett, \& Brown, 2004). The interests directly 2 influence the projects selected, but they will not be precisely converted into action, since other variables are 
also involved in the process. Generally, aspects such as culture, maturity, life projects and levels of indecision interfere with the stability of interests; however, it is considered that over the years and with a growing level of education they get consolidated (Armstrong, Su, \& Rounds, 2011; Murgo, Barros, \& Sena, 2018). On the other hand, self-efficacy, since it is the belief that it is possible to perform a given action successfully, precedes the development of interests, thus delimiting the differences between the concepts (Moreira, Ambiel, \& Nunes, 2018).

As for the formation of professional interests, the Theory of Vocational Personality and Work Environments (Holland, 1975) is one of the most accepted and used in the world scenario (Hansen, 2011; Ribeiro, 2015). The theorist suggests that, over time, individuals develop preferences for certain activities, in line with their experiences, such as parental, biological, social, cultural and physical environment influences. These preferences tend to become interests, leading to the development of specific skills (Mansão, Noronha, \& Ottati, 2011). Thus, competencies generate an individual disposition that is associated with specific thinking and acting styles (Holland, 1997). Based on these assumptions, Holland (1975) defined six types of vocational profiles: Realistic, Investigative, Artistic, Social, Entrepreneur and Conventional.

It should be noted that although the TSCDC and Holland's theory aim to explain aspects associated with the career, the latter differs in terms of the focus given to the variables in their relevant models. In Holland's theory (1975), interests are the main variable and are understood as an expression of personality, resulting from experiences that throughout life form patterns of preferences that guide individuals to choose occupations and environments congruent with their primary interests. Although the TSCDC shares this general assumption (Lent et al., 1994), this model includes other resources that complement the choice process, with interests becoming secondary since they are preceded by self-efficacy and expected outcome and that the choice motivation becomes driven more by the goals than by the congruence. However, even with the approach differences, the two theories share the fact that interests stabilize throughout life and that they can lead individuals towards their occupational choices (Lamas, 2017), which justifies the search for associations between variables.

Internationally, a greater variety of studies on professional interests and self-efficacy are available. Regarding the relationship between the constructs, a meta-analysis study identified that self-efficacy and interests are independent constructs correlating moderately, sharing approximately one third of variance. In contrast, when interests are reviewed based on Holland's theory, there is an increase in shared variance that ranges from $25 \%$ to $46 \%$ according to the types reviewed (Rottinghaus, Larson, \& Borgen, 2003). In turn, Grigg, Perera, Mcllveen, and Svetleff (2018) when analyzing self-efficacy and interests in mathematics pointed out that previous experiences in the area of interest positively predict the levels of self-efficacy in the domain, as well as interests in an area can predict the levels of self-efficacy. In addition, responding to an instrument of interest and receiving feedback on the outcome that allows greater self-knowledge can contribute to an increase in self-efficacy levels (Işık, 2014). In contrast, Isaac, Walters, and McLachlan (2015) found that, in turn, self-efficacy is associated with increased levels of interest.

In relation to gender, Falk, Rottinghaus, Casanova, Borgen, and Betz (2017) found that gender is a moderator for self-efficacy and for realistic interests so that women exhibit lower levels than men. However, although men tend to exhibit greater realistic, social and conventional interests, the magnitudes of these differences were considered small, ranging from 0 to $7 \%$ (Rottinghaus et al., 2003). It should be noted that Holland's theory is criticized for possibly presenting a gender bias in its conceptualization, since it was developed from studies with predominantly male samples, which is one of the reasons for the differences in the type of interests between men and women and not only as a function of a valid variance (Fouth, McHugh, Bertoch, \& Reardson, 2014; Gottfredson, 2009). 
In Brazil, studies have sought to address self-efficacy in the context of career development (Ambiel \& Noronha, 2014; Masotti \& Noronha, 2015; Oliveira, Silva, Garcia, Melo-Silva, \& Teixeira, 2014; Prisco et al., 2013). However, new investigations that allow verifying the relationship between self-efficacy and professional interests (Nunes \& Noronha, 2011) may be of great importance in advancing discussions to expand the topic. Therefore, this study aimed to review the relationships between self-efficacy beliefs for a professional choice and professional interests based on Holland's hexagonal model in a sample of high school students.

In addition, possible differences were found depending on sociodemographic variables, especially those that refer to gender, school grade and type of school. In this regard, the study seeks to discuss potential associations between such variables and the formation of interests and beliefs, assuming that the school context can be configured as a potentializing environment for the development of adolescents and thereby impact the formation of self-efficacy positive beliefs and interest profiles. In addition, we sought to observe through linear regression analysis which types of professional interests are predictors of self-efficacy beliefs from the indications that interests do influence the development and level of self-efficacy (Grigg et al., 2018; Işık, 2014), as well as which demographic variables (gender, school grade, type of school and age) predict the factors of self-efficacy for professional choice.

\section{Method}

\section{Participants}

A total of 613 adolescents from cities in the interior of the State of São Paulo participated in this survey, 350 of whom were female (57.1\%) and 263 male (42.9\%), with ages ranging between 15 and 19 years $(M=16.65 ; S D=0.75)$, from public schools $(n=515 ; 84.0 \%)$ and private schools $(n=97 ; 15.8 \%)$, with one participant not informing the type of school. All participants were in High School at the time of collection, and 22 (3.6\%) of them reported they were in the 1st year, 90 (14.7\%) in the 2nd year and 500 $(81.6 \%)$ in the $3 r d$ year. One of the participants did not inform the school year.

\section{Instruments}

Self-Directed Search Career Explorer (SDS) - CE Form - (Holland, 1975); the SDS Brazilian version is called Self-Directed Search Questionnaire (Primi, Mansão, Muniz, \& Nunes, 2010). The instrument assesses professional interests and is structured in four sections: activities, competencies, careers and skills. The sections include items that address the six types proposed by Holland: Realistic (R), Investigative (I), Artistic (A), Social (S), Entrepreneur (E) and Conventional (C). The answers in the activities, skills and careers sections are dichotomous - $\mathrm{Y}$ (yes) or $\mathrm{N}$ (no) and include 66 items each. The responses in the Skills section are based on a seven-point Likert-type scale, ranging from 1 (poor skill) to 7 (great skill) and this section includes 12 items. Regarding precision, the instrument presented satisfactory indexes in the normative sample, obtaining a Cronbach's alpha coefficients ranging from 0.87 (Realistic) and 0.90 (Conventional). In this study, the instrument presented coefficients varying between 0.60 (Realistic) and 0.70 (Conventional).

Professional Choice Self-Efficacy Scale (EAE-EP, Escala de Auto-Eficácia para Escolha Profissional) (Ambiel \& Noronha, 2012): this instrument aims to investigate personal beliefs in relation to the ability to engage in professional choice tasks. It consists of 47 items answered on a four points Likert-type scale, ranging from 1 (little) to 4 (much). The scale consists of four factors: Self-efficacy for Self-assessment, Self-efficacy for Collecting Occupational Information, Self-efficacy in the Search for Practical Professional Information 
and Self-efficacy for Future Planning, in addition to a General Score. In the normative study, the instrument had a precision coefficient from adequate to excellent, ranging from 0.79 to 0.94 . In the present study, the instrument presented Cronbach's alpha coefficients ranging from 0.74 (Collection of occupational information) to 0.91 (General Score).

\section{Procedures}

The project was authorized by the Research Ethics Committee of the Universidade do Oeste Paulista (CAAE: 30888314.0.0000.5515). Data collection took place in Professional Guidance workshops offered to students from schools in the interior of the State of São Paulo by the Psychology course of a private university in the same region. The signing of the Free and Informed Consent Form by the guardians was provided by the school team, so that only adolescents who delivered the duly signed document to the school's coordinators participated in the workshops and data collection. In addition to the guardians' consent, on the day of collection, the adolescents signed the Free and Informed Consent Form agreeing with voluntary participation in the investigation. The instruments were applied collectively on days and time previously scheduled for the university workshop.

\section{Data Analysis}

The data were reviewed using the SPSS${ }^{\circledR} \mid \mathrm{BM}^{\circledR}$ Software (version 22) with descriptive statistics to characterize the sample. Subsequently, inferential statistics were used with the Student's t test and Analysis of Variance (ANOVA) for the differentiation between groups, calculation of Cohen's $d$ to verify the size of the effect of differences and Pearson's Correlation analysis between the factors of the instruments. In addition, linear regression analyses were performed with the Enter method, using Holland's vocational personality types as an independent variable and gender, age, school grade, school type and the self-efficacy factors assessed by EAE-EP as dependent variable. The parameters established by Dancey and Reid (2013) were used to interpret the correlations and to interpret the effect size, following Cohen's recommendations (1988) in which results up to 0.30 are considered to have little effect, 0.40 to 0.70 moderate effect and above 0.80 as having a large statistical effect.

\section{Results}

Initially, the descriptive statistics of the instruments used in this study were calculated, by verifying Means $(M)$ and Standard Deviations (SD), and in the SDS the lowest mean were found in the types Realistic $(M=13.97 ; S D=9.61)$ and Conventional $(M=14.84 ; S D=10.37)$ and the highest in Social $(M=22.53$; $S D=10.72)$ and Entrepreneur $(M=22.08 ; S D=10.41)$. In relation to the means in the EAE-EP, the Future Planning factor obtained the lowest mean $(M=26.13 ; S D=4.166)$ and the highest was in the Occupational Information Collection factor $(M=34.07 ; S D=5.604)$. Then the Student's $t$ test was used in order to verify differences in responses according to the variables gender, type of school and age, and for the latter category the sample was divided into two groups, the first up to 16 years of age and the second above 16 years.

Regarding the professional interests, differences were initially sought based on gender, with women presenting higher mean in the Social type $(t(604)=6.737 ; p<0.001)$ when compared to men while the latter showed higher mean in the Realistic types $(t(608)=-13.121, p<0.001)$, Entrepreneur $(t(608)=-4.785, p<0.001)$ and Conventional $(t(607)=-2.947, p<0.001)$ and the effect size was strong 
for the Realistic type $(d=0.90)$, moderate for the Social type $(d=0.55)$ and small for the Entrepreneur $(d=0.38)$ and Conventional types $(d=0.24)$. In the comparison by type of school, students from private schools had higher mean in the Realistic types $(t(607)=-3,366, p<0,001)$, Investigative $(t(604)=-2.567$, $p<0.05)$ and Entrepreneur $(t(607)=-2.236, p<0.001)$ with small effect size $(d=0.35 ; d=0.28$ and $d=0.24$ respectively) when compared with students from public schools. Regarding age, differences between the participants were found only in the Conventional type, with students aged 16 years or less showing higher scores $(t(607)=2.007, p<0.001)$, but with small effect size $(d=0.16)$.

Regarding self-efficacy beliefs, the gender variable generated a significant difference only in the Occupational Information Collection factor, in which women exhibited higher means when compared to men $(t(531)=2.889, p<0.001)$. In the comparison by type of school, students from private schools differed from students from public schools with higher scores in all the domains assessed by EAE-EP: Self-assessment $(t(145)=-2.175, p<0.05)$, Collection of Occupational Information $(t(610)=-2.768, p<0.05)$, Search for Practical Professional Information $(t(610)=-2.531, p<0.05)$, Future Planning (t $(609)=-3.966, p<0.001)$ and General Score $(t(609)=-3.197, p<0.05)$. When considering age, only in the Factor Searching for Professional Information Practices significant differences were found, in which participants over 16 years of age obtained higher mean in relation to younger participants $(t(455)=-2.047, p<0.05)$. In all the differences found, the effect size was small with Cohen's $d$ ranging between 0.10 and 0.40 . Then, we sought to verify possible differences in the types of interests assessed by the SDS and in the EAE-EP factors according to the school grade using ANOVA and Tukey's post hoc test. In the SDS, only the Investigative and Entrepreneur types did not show significant results, while in EAE-EP, no statistically significant results were found in three of the four factors evaluated, in addition to the general score (Table 1).

It was observed that there was the formation of subsets in all types of professional interests that presented significant results. The 1 st year students had the highest scores in all types in relation to the 2 nd and 3rd year students, a result that may be related to the fact that they are still not so pressed in terms of decision and professional exploration, generating high levels of interest in different areas that may not actually

Table 1

Analysis of variance and Tukey's test for SDS typologies, EAE-EP factors and school grades

\begin{tabular}{|c|c|c|c|c|c|}
\hline \multirow{2}{*}{ Factor } & \multirow{2}{*}{$d f$} & \multirow{2}{*}{$F$} & \multirow{2}{*}{ School grade } & \multicolumn{2}{|c|}{ Subsets } \\
\hline & & & & 1 & 2 \\
\hline \multirow[t]{3}{*}{ Realistic SDS } & 2 & $4.498^{*}$ & 2nd year & 12.90 & \\
\hline & & & 3rd year & 13.90 & \\
\hline & & & 1st year & & 19.68 \\
\hline \multirow[t]{3}{*}{ Artistic SDS } & 2 & $3.516^{*}$ & 2nd year & 15.00 & \\
\hline & & & 3rd year & 16.56 & \\
\hline & & & 1st year & & 22.14 \\
\hline \multirow[t]{3}{*}{ Social SDS } & 2 & $5.045^{*}$ & 2nd year & 20.69 & \\
\hline & & & 3rd year & 22.69 & \\
\hline & & & 1st year & & 28.00 \\
\hline \multirow[t]{3}{*}{ Conventional SDS } & 2 & $4.912^{*}$ & 3rd year & 14.32 & \\
\hline & & & 2nd year & 16.33 & 16.33 \\
\hline & & & 1st year & & 20.55 \\
\hline \multirow[t]{3}{*}{ Future Planning EAE-EP } & 2 & $3.891^{*}$ & 1st year & 24.41 & \\
\hline & & & 2nd year & 25.40 & \\
\hline & & & 3rd year & 26.33 & \\
\hline
\end{tabular}

Note: ${ }^{*} p<0.05$.

$6 d f$ : degrees of freedom; EAE-EP: Professional Choice Self-Efficacy Scale; F: Statistics; SDS: Self-Directed Search Career Explorer. 
be real. The Future Planning factor was the only one from EAE-EP with significant results; however, it did not generate subgroups in group differentiation. However, the highest scores were obtained by students in the 3rd year of high school, indicating that this group tends to be more likely to believe in its ability to reflect on issues related to their professional future. Subsequently, we sought to verify the correlations between the factors (Table 2).

The correlations obtained were mostly null or without statistical significance. Among those statistically significant, the Investigative type showed correlations with the three factors and with the EAE-EP General Score, and the correlations were positive between the type and the factors Occupational Information Search, Future Planning and General Score and negative with the Occupational Information Collection factor, but with small magnitude in all coefficients. This data suggests that the more the person has investigative interests, the more he or she tends to have beliefs in his/her ability to get in touch with professionals in his/her preferred area, plan his/her future and, in general, has a higher level of self-efficacy for the professional choice. Subsequently, partial correlations were performed controlling the variables gender, type of school and school grade; however, the results did not show significant changes.

Finally, linear regressions were performed using the self-efficacy factors for professional choice as the dependent variable and the six types of professional interests as independent variables. Preference for this model for the analysis was based on the assumptions of Lent et al. (2004) in which self-efficacy in specific domains is located after the professional interests, between goals and actions. Table 3 shows the results of the regression analysis.

The results indicated that in the self-assessment factor the determination coefficient (adjusted $R^{2}$ ) explained $14.6 \%$ of the variability $F(10)=1.248 ; p=0.25$, and the types Investigative, Artistic, Social and the type of school obtained statistical significance in the prediction of the variable $(p<0.05)$. In the Occupational Information Collection factor, the adjusted $R^{2}$ value indicates the prediction of $30.4 \%$ of the variance $(F(10)=5.811 ; p=0.000)$, in which investigative and artistic interests, as well as gender, were statistically significant in the prediction. In turn, the Search Factor for Practical Professional Information $\left(R^{2}=25.9 \% ; F(10)=4.166, p=0.000\right)$ was predicted by artistic and social investigative interests and by the type of school. Regarding Future Planning, the determination coefficient explained $32.4 \%$ of the variability $(F(10)=6.683 ; p=0.000)$ with the investigative, artistic and entrepreneurial types and the variables age, gender and type of school contributing in a statistically significant way in predicting the variable. Finally, in relation to the General Score, the adjusted $R^{2}$ indicated the prediction of $26.6 \%$ of the variance $(F(10)=4.341 ; p=0.000)$, and again the artistic typology was the only one that was significant in the prediction of beliefs of self-efficacy for the professional choice.

Table 2

Correlations between SDS typologies and EAE-EP factors

\begin{tabular}{lccccc}
\hline Typologies & Self-assessment & $\begin{array}{c}\text { Collection of occupational } \\
\text { information }\end{array}$ & $\begin{array}{c}\text { Search for practical professional } \\
\text { information }\end{array}$ & Future planning & General score \\
\hline Realistic & 0.04 & -0.03 & 0.01 & 0.02 & 0.02 \\
Investigative & 0.06 & $-0.18^{* *}$ & $0.14^{* *}$ & $0.15^{* *}$ & $0.15^{* *}$ \\
Artistic & -0.03 & 0.06 & -0.05 & $-0.13^{* *}$ & -0.07 \\
Social & 0.05 & $0.09^{*}$ & $0.16^{* *}$ & 0.02 & $0.10^{*}$ \\
Entrepreneurial & 0.06 & $0.09^{*}$ & 0.07 & $0.09^{*}$ & $0.09^{*}$ \\
Conventional & 0.03 & $0.08^{*}$ & 0.08 & 0.05 & 0.07 \\
\hline
\end{tabular}

Note: ${ }^{*} p<0.05 ;{ }^{* *} p<0.00$.

EAE-EP: Professional Choice Self-Efficacy Scale; SDS: Self-Directed Search Career Explorer. 
Table 3

Linear regression of professional interests and demographic variables as predictors of Self-efficacy beliefs for professional choice

\begin{tabular}{|c|c|c|c|c|}
\hline Dependent variable & Model & Standardized Beta & $t$ & $p$ \\
\hline \multirow[t]{12}{*}{ Self-assessment } & Constant & & 6.953 & 0.00 \\
\hline & Realist & -0.020 & -0.383 & 0.70 \\
\hline & Investigative & 0.140 & 3.119 & 0.00 \\
\hline & Artistic & -0.138 & -3.179 & 0.00 \\
\hline & Social & 0.096 & 2.037 & 0.04 \\
\hline & Entrepreneur & 0.091 & 1.753 & 0.08 \\
\hline & Conventional & -0.010 & -0.192 & 0.84 \\
\hline & Gender & -0.021 & -0.434 & 0.66 \\
\hline & Age & -0.031 & -0.637 & 0.52 \\
\hline & Series & 0.069 & 1.404 & 0.16 \\
\hline & School Type & 0.117 & 2.858 & 0.00 \\
\hline & $R^{2}$ & & $14.6 \%$ & \\
\hline \multirow[t]{12}{*}{ Collection of occupational information } & Constant & & 6.898 & 0.00 \\
\hline & Realistic & -0.071 & -1.399 & 0.16 \\
\hline & Investigative & 0.189 & 4.269 & 0.00 \\
\hline & Artistic & -0.111 & -2.586 & 0.01 \\
\hline & Social & 0.032 & 0.685 & 0.49 \\
\hline & Entrepreneur & 0.103 & 2.014 & 0.04 \\
\hline & Conventional & 0.019 & 0.358 & 0.72 \\
\hline & Gender & -0.115 & -2.383 & 0.01 \\
\hline & Age & -0.066 & -1.367 & 0.17 \\
\hline & Series & 0.093 & 1.931 & 0.05 \\
\hline & School Type & 0.101 & 2.487 & 0.01 \\
\hline & $R^{2}$ & & $30.4 \%$ & \\
\hline \multirow[t]{12}{*}{ Search for practical professional information } & Constant & & 3.209 & 0.00 \\
\hline & Realistic & -0.042 & -0.822 & 0.41 \\
\hline & Investigative & 0.117 & 2.622 & 0.00 \\
\hline & Artistic & -0.126 & -2.912 & 0.00 \\
\hline & Social & 0.172 & 3.657 & 0.00 \\
\hline & Entrepreneur & 0.033 & 0.637 & 0.52 \\
\hline & Conventional & 0.019 & 0.358 & 0.72 \\
\hline & Gender & 0.057 & 1.154 & 0.24 \\
\hline & Age & 0.037 & 0.757 & 0.44 \\
\hline & Series & 0.012 & 0.246 & 0.80 \\
\hline & School Type & 0.096 & 2.324 & 0.02 \\
\hline & $R^{2}$ & & $25.9 \%$ & \\
\hline \multirow[t]{12}{*}{ Future planning } & Constant & & 6.987 & 0.00 \\
\hline & Realistic & -0.023 & -0.447 & 0.65 \\
\hline & Investigative & 0.161 & 3.676 & 0.00 \\
\hline & Artistic & -0.178 & -4.182 & 0.00 \\
\hline & Social & 0.026 & 0.567 & 0.57 \\
\hline & Entrepreneur & 0.125 & 2.458 & 0.01 \\
\hline & Conventional & -0.025 & -0.477 & 0.63 \\
\hline & Gender & -0.004 & -0.091 & 0.92 \\
\hline & Age & -0.094 & -1.974 & 0.04 \\
\hline & Series & 0.156 & 3.262 & 0.00 \\
\hline & School Type & 0.146 & 3.613 & 0.00 \\
\hline & $R^{2}$ & & $32.4 \%$ & \\
\hline \multirow[t]{12}{*}{ General score } & Constant & & 6.953 & 0.00 \\
\hline & Realistic & -0.020 & -0.383 & 0.70 \\
\hline & Investigative & 0.140 & 3.119 & 0.00 \\
\hline & Artistic & -0.138 & -3.179 & 0.00 \\
\hline & Social & 0.096 & 2.037 & 0.04 \\
\hline & Entrepreneur & 0.091 & 1.753 & 0.08 \\
\hline & Conventional & -0.101 & -0.192 & 0.84 \\
\hline & Gender & -0.021 & -0.434 & 0.66 \\
\hline & Age & -0.031 & -0.637 & 0.52 \\
\hline & Series & 0.069 & 1.404 & 0.16 \\
\hline & School Type & 0.117 & 2.858 & 0.00 \\
\hline & $R^{2}$ & & $26.6 \%$ & \\
\hline
\end{tabular}

$8 \quad$ Note: $p$ : Value; $R^{2}$ : Adjusted R-squared; $t$ : statistic. 


\section{Discussion}

The aim of this study was to assess the relationships between self-efficacy beliefs and professional interests based on Holland's hexagonal model, as well as potential differences in the functions of demographic variables and what types of professional interests and demographic variables are predictors of self-efficacy beliefs in high school students. Studies of this nature are important considering the lack of research in the Brazilian framework with both constructs despite their wide use in vocational guidance processes (Oliveira et al., 2014; Prisco et al., 2013). Regarding the differences in the means of the instruments due to demographic variables, the results indicated that women differed significantly from men with greater social interests while male participants obtained higher scores in Realistic, Entrepreneur and Conventional interests.

Such result corroborates what the literature has reported in relation to the functioning of the interests understood from Holland, in which, men traditionally score higher in Realistic and women in Social (Armstrong et al., 2011; Su, Rounds, \& Armstrong, 2009). Initially, it is important to emphasize that Holland's theory was developed in a historical context in which women had little access to work and were restricted to care professions (Social type). The author himself (Holland, 1975) takes as a limitation of his theory the fact that his research was carried out mainly with a male audience, a criticism endorsed by other authors (Fouth et al., 2014; Gottfredson, 2009).

It is important to emphasize that such differences in variability influence, at the same time that they are influenced, the relationship between men and women regarding their professional interests, causing gender disparities that often range from academic training to practices in certain work contexts. When it comes to social impacts, these differences, when not critically analyzed, can contribute to maintaining the discrepancy in the proportion of men and women in specific fields, such as a greater concentration of men in technology and exact areas (Paessler, 2015). Still, in order to have comprehensive assessments and adequately explain these imbalances, variations in the distributive characteristics of the group need to be, even if reasonably, homogeneous. (Voracek, Mohr, \& Hagmann, 2013).

However, the current transformations of the 21st century (Duarte, 2015; Savickas, 2015) have reconfigured the work scenario, with the greater insertion of women in different fields. In this sense, one can think that currently with greater possibilities of professional choice, the pattern of interest should also have changed. Thus, it is suggested that studies should be conducted to assess the differential functioning of SDS items to check for potential biases related to gender in the instrument, since it is already known in the literature that the magnitude of these differences is null or small (Rottinghaus et al., 2003); this was also an aspect observed in the present study, which suggests that the differences are possibly related to the instrument's bias and not to the valid variance (Gottsfredson, 2009).

Still in relation to professional interests, differences were observed depending on the school grade. The high school 1st year students obtained higher mean which were different from the other grades students' mean in the Realistic, Artistic, Social and Conventional types. When comparing age groups, students aged 16 and below showed higher scores only in the Conventional type. In general, there is an expectation that over the years and with the growth of the instructional level, interests will become more stable and defined (Armstrong et al., 2011); however, such stability also depends on other aspects such as the life project clarity, maturity for a choice, culture and low levels of indecision. Thus, 3rd year students may not have presented higher scores in the types of interest due to the fact that they compose an audience that in fact deals with the career transition and potential professional choice, an aspect that can generate indecision and insecurity (Murgo et al., 2018). This result highlights the importance of career development interventions with graduating students in order to facilitate their decision-making process. 
Regarding the differences in the levels of self-efficacy, the results indicated that private schools students differed from public schools students because of higher mean in all the dimensions of the EAE-EP. This result is similar to that found in the study by Noronha, Freitas, Piovezan, and Joly (2013) in which private schools students produced higher scores in the EAE-EP dimensions. When considering that self-efficacy beliefs come from sources that also involve the social and cultural aspects (i.e., source of vicarious learning) (Lent et al., 1994), the importance of the democratization of Professional and Career Guidance is reaffirmed, and should contemplate public schools' students - traditionally excluded from the processes (Duarte, 2015) -, since these interventions can assist in the development of positive beliefs about themselves and the ability to establish relationships and explore the world of work for a possible choice (Ambiel \& Noronha, 2014).

The correlations between the SDS and EAE-EP factors were mostly null or without statistical significance, with the highest statistically significant coefficients located between the Investigative type and the Professional Information Collection, Search for Occupational Information, Future Planning and General Score factors. Although the magnitude of the correlations was weak, the results are consistent with the description of this type of vocational personality. Holland (1975) has conceptualized that people with investigative interests are interested in activities that involve the exploration and manipulation of ideas and problem solving; these aspects can contribute to a higher elevation of the interests profile and to the development of positive beliefs in relation to the capacity to manage their own career. Thus, the findings of this study are pertinent when identifying this group as being the one which exhibits the greatest positive correlations with the beliefs of selfefficacy for the professional choice, since the maintenance of the belief and its increase is highly dependent on exploration and actual involvement with different tasks (Lent et al., 1994).

Finally, when analyzing the results of linear regression, in general, all the factors of self-efficacy assessed by EAE-EP were predicted negatively by Artistic interests and positively by the Investigative type. Thus, the results suggest different forms of career management according to the characteristics of each interest profile. Considering Holland's arguments (1975), the artistic and investigative profiles differ in their interests, values, skills and self-concepts, which implies assuming that individuals will adopt different strategies to explore opportunities or make career decisions. In this sense, it is essential that interventions in Professional and Career Guidance be outlined based on the characteristics and needs of customers and not through a closed or common script to be applied to all those who seek the service.

Along the same line, it was observed that, besides the aforementioned typologies that were significant predictors of all factors, Self-Assessment, Search for Practical Professional Information and the General Score were positively predicted by social interests and the type of school. The Occupational Information Collection factor was negatively predicted by the gender variable and positively by the grade and type of school while Future Planning was positively predicted by entrepreneurial interests, grade and type of school and negatively by age. Such results suggest that the characteristics of the Social and Entrepreneurial type, such as the preference for socializing and interacting with other people (Holland, 1975) are important in the process of professional selection, as well as being a source of vicarious learning, an aspect that contributes for the development of positive self-efficacy beliefs (Bandura, 1997; Lent et al., 1994). In turn, demographic variables also contribute to the prediction of beliefs. In this sense, it is important that interventions include audiences from all high school grades and are not focused only on third year students in order that the professional choice be a process and not an act to be performed in a decontextualized way, under pressure.

In order to summarize the investigation findings, some considerations deserve to be highlighted. Therefore, it is necessary to consider the dynamics of career choice processes, which require that the Professional and Career Guidance area addresses several elements involved in decision making, such as life experience, skills, beliefs, interests and the contemporary occupational possibilities demands. The analyses that aimed to verify associations between self-efficacy and professional interests revealed that the correlations between the SDS and EAE-EP factors were mostly null or without statistical significance. 
As for the limitations of the study, it is necessary to consider that the sample was obtained from a single region of Brazil and that high school third year students prevailed. It is also worth mentioning the differences in the total number of participants regarding gender (greater number of women) and the type of school (predominantly students from public schools), indicating a disparity in the distribution of participants. Conceptually, a greater representativeness of the sample would allow assessing whether the investigated constructs would correlate or not with other variables that were not addressed. The diversification of the sample regarding the regions and the balance in the number of participants in relation to the type of school, would favor the detailed analysis on the interference of demographic variables.

It is essential to draw attention to the need to expand interventional actions in Vocational and Career Guidance for young people and adolescents, especially in connection with public schools, given that students in this segment have less access to services of this nature and that in the present study, the scores on the selfefficacy scale of public school participants were lower when compared to those of students of private schools. In this regard, the present investigation aimed to contribute with the work of the counselors regarding the insertion of discussions in vocational guidance that help adolescents to understand the impact of interests and self-efficacy beliefs in the development of their professional projects, bringing more systematic data on such constructs.

Finally, the relevance of focusing on personal and occupational data is emphasized when thinking about a professional choice and career planning. In the spectrum of personal data, interests allow individuals to recognize their inclinations, to fulfill their desires and to realize their talents, while self-efficacy beliefs can enhance the recognition of positive capacities in relation to themselves and in relation to the occupations they can perform in the world of work.

\section{Contributors}

C. S. MURGO planned and carried out the project, data collection and owns the database. L. O. BARROS performed the analyses and wrote the results and discussion session. B. C. S. SENA wrote the introduction and revised manuscript and author's guide. All authors contributed to the writing of the manuscript.

\section{References}

Ambiel, R. A. M., \& Noronha, A. P. P. (2012). Autoeficácia para escolha profissional: teoria, pesquisas e avaliação. Psicologia em Pesquisa, 6(2), 171-178. http://dx.doi.org/10.5327/ z1982-12472012000200010

Ambiel, R. A. M., \& Noronha A. P. P. (2014). Escala de autoeficácia para escolha profissional (EAE-EP): manual técnico. São Paulo: Casa do Psicólogo.

Armstrong, P. I., Su, R., \& Rounds, J. (2011). Vocational interests: the road less traveled. In T. Chamorro-Premuzic, S. von Stumm, \& A. Furnham (Eds.), The Wiley-Blackwell handbook of individual differences (pp.608-631). Hoboken: Wiley-Blackwell. http://dx.doi.org/10.1002/9781444343120.ch23

Bandura, A. (1997). Self-efficacy, the exercise of control. New York: Freeman and Company.

Choi, B. Y., Park, H., Yang, E., Lee, S. K., Lee, Y., \& Lee, S. M. (2011). Understanding career decision self-efficacy. Journal of Career Development, 39(5), 443-460. http://dx.doi.org/ 10.1177/0894845311398042

Cohen, J. (1988). Statistical power analysis for the behavioral sciences (2 ed.). Hillsdale: Lawrence Erlbaum Associates.

Dancey, C. P., \& Reid, J. (2013). Estatística sem matemática para psicologia. Porto Alegre: Artmed.

Duarte, M. E. (2015). Inovação em orientação e aconselhamento de carreira: mitos e realidades. Revista Brasileira de Orientação Profissional, 16(2), 110-121. Recuperado de http://pepsic.bvsalud.org/pdf/rbop/v16n2/03.pdf

Falk, N. A., Rottinghaus, P. J., Casanova, T. N., Borgen, F. H., \& Betz, N. E. (2017). Expanding women's participation in STEM: insights from parallel measures of self-efficacy and interests. Journal of Career Assessment, 25(4), 571-584. http://dx.doi.org/10.1177/1069072716665822 
Foutch, H., McHugh, E. R., Bertoch, S. C., \& Reardon, R. C. (2014). Creating and using a database on holland's theory and practical tools. Journal of Career Assessment, 22(1), 188-202. http://dx.doi.org/10.1177/1069072713492947

Gottfredson, G. D. (2009). John L. Holland (1919-2008). American Psychologist, 64(6), 561. http://dx.doi.org/10.1037/a0 016602

Grigg, S., Perera, H. N., Mcllveen, P., \& Svetleff, Z. (2018). Relations among math self-efficacy, interest, intentions, and achievement: a social cognitive perspective. Contemporary Educational Psychology, 53, 73-86. http://dx.doi. org/10.1016/j.cedpsych.2018.01.007

Hansen, J. I. C. (2011). Remembering John L. Holland, PhD. The Counseling Psychologist, 39(8), 1212-1217. http:// dx.doi.org/10.1177/0011000011423553

Holland, J. L. (1975). Técnica de la elección vocacional: tipos de personalidad y modelos ambientales. Ciudad de México: Trillas.

Holland, J. L. (1997). Making vocational choices: a theory of vocational personalities and work environments. Englewood Cliffs: Prentice-Hall.

Isaac V., Walters, L., \& McLachlan, C. S. (2015). Ion between self-efficacy, career interest and rural career intent in Australian medical students with rural clinical school experience. BMJ Open, 5(12). http://dx.doi.org/10.1136/ bmjopen-2015-009574

Işık, E. (2014). Effects of a brief interest inventory intervention on career decision self-efficacy. Australian Journal of Guidance and Counseling, 24(02), 215-226. http://dx.doi.org/10.1017/jgc.2014.13

Lamas, K. C. A. (2017). Concept and relevance of vocational interests in career development: a theoretical study. Trends in Psychology, 25(2), 719-732. http://dx.doi.org/10.9788/TP2017.2-16En

Lent, R. W. (2016). Self-efficacy in a relational world: Social cognitive mechanisms of adaptation and development. The Counseling Psychologist, 44(4), 573-594. http://dx.doi.org/10.1177/0011000016638742

Lent, R. W., Brown, S. D., \& Hackett, G. (1994). Towards a unifying social cognitive theory of career and academic interests, choices and performance. Journal of Vocational Behavior, 45(1), 79-122. http://dx.doi.org/10.1006/jvbe.1994.1027

Lent, R. W., Hackett, G., \& Brown, S. D. (2004). Una perspectiva social cognitiva de la transición entre la escuela y el trabajo. Revista Evaluar, 4, 1-22. Recuperado el https://revistas.unc.edu.ar/index.php/revaluar/article/view/596/565

Lent, R. W., Ireland, G. W., Penn, L. T., Morris, T. R., \& Sappington, R. (2017). Sources of self-efficacy and outcome expectations for career exploration and decision-making: a test of the social cognitive model of career self-management. Journal of Vocational Behavior, 99, 107-117. http://dx.doi.org/10.1016/j.jvb.2017.01.002

Mansão, C. S. M., Noronha, A. P. P., \& Ottati, F. (2011). Interesses profissionais: análise correlacional entre dois instrumentos de avaliação. Revista Brasileira de Orientação Profissional, 12(2), 175-184. Recuperado de http://pepsic.bvsalud.org/ $\mathrm{pdf} / \mathrm{rbop} / \mathrm{v} 12 \mathrm{n} 2 / 05 . \mathrm{pdf}$

Masotti, D. R., \& Noronha, A. P. P. (2015). Estudo correlacional entre interesses profissionais e autoeficácia com tecnólogos. Interação em Psicologia, 19(1), 107-117. http://dx.doi.org/10.5380/psi.v19i1.28920

Moreira, T. C., Ambiel, R. A. M., \& Nunes, M. F. O. (2018). Escala de fontes de autoeficácia para escolha profissional: construção e estudos psicométricos iniciais. Trends in Psychology, 26(1), 47-60. http://dx.doi.org/10.9788/tp2018.1-03pt

Murgo, C. S., Barros, L. O., \& Sena, B. C. S. (2018). Associações entre estilos parentais, interesses e indecisão profissional em estudantes do Ensino Médio. Psico-USF, 23(4), 693-703. http://dx.doi.org/10.1590/1413-82712018230409

Noronha, A. P. P., Freitas, P. C. S., Piovezan, N. M., \& Joly, M. C. R. A. (2013). Afetos positivos e negativos e autoeficácia em jovens do ensino médio. Revista de Psicología Trujillo, 15(1), 9-21. Recuperado de http://revistas.ucv.edu.pe/index. php/R_PSI/article/view/206/117

Nunes, M. F. O., \& Noronha, A. P. P. (2011). Associações entre auto-eficácia para atividades ocupacionais e interesses em adolescentes. Psicologia: Reflexão e Crítica, 24(1), 1-9. http://dx.doi.org/10.1590/S0102-79722011000100002

Oliveira, M. C., Silva, B. R., Garcia, R. G., Melo-Silva, L. L., \& Teixeira, M. A. P. (2014). Escala de autoeficácia no aconselhamento de carreira: adaptação e evidências de validade. Avaliação Psicológica, 13(3), 371-381. Recuperado de http://pepsic.bvsalud.org/pdf/avp/v13n3/v13n3a09.pdf

Paessler, K. (2015). Sex differences in variability in vocational interests: evidence from two large samples. European Journal of Personality, 29(5), 568-578.

Pajares, F., \& Olaz, F. (2008). Teoria social cognitiva e auto-eficácia: uma visão geral. In A. Bandura, R. G. Azzi, \& S. Polydoro (Eds.), Teoria cognitiva: conceitos básicos (pp.97-114). Porto Alegre: Artmed.

Primi, R., Mansão, C. M., Muniz, M., \& Nunes, M. F. O. (2010). SDS - Questionário de Busca Auto dirigida: ferramenta de orientação vocacional e de carreira. São Paulo: Casa do Psicólogo. 
Prisco, A. P. K., Martins, C. R., Nunes, M. F. O. (2013). Estudos sobre autoeficácia aplicada ao desenvolvimento de carreira no brasil: uma revisão. Revista Brasileira de Orientação Profissional, 15(1), 111-118. Recuperado de http://pepsic. bvsalud.org/pdf/rbop/v14n1/11.pdf

Ribeiro, E. C. A. (2015). Interesses profissionais em diferentes percursos educativos: Contributos para a validação da versão portuguesa do SDS: Self-Directed Search (Dissertação de mestrado não-publicado). Universidade de Lisboa, Portugal. Recuperado de http://repositorio.ul.pt/bitstream/10451/23160/1/ulfpie047677_tm.pdf

Rottinghaus, P. J., Larson, L. M., \& Borgen, F. H. (2003). The relation of self-efficacy and interests: a meta-analysis of 60 samples. Journal of Vocational Behavior, 62(2), 221-236. http://dx.doi.org/10.1016/\$0001-8791(02)00039-8

Savickas, M. L. (2015). Life-Design counseling manual. Rootstown: Hachai Publishing.

Su, R., Rounds, J., \& Armstrong, P. I. (2009). Men and things, women and people: a metaanalysis of gender and interests. Psychological Bulletin, 135, 859-884. http://dx.doi.org/10.1037/a0017364

Voracek, M., Mohr, E., \& Hagmann, M. (2013). On the importance of tail ratios for psychological science. Psychological Reports, 112, 872-886. http://dx.doi.org/10.2466/03.PR0.112.3.872-886

Whiston, S. C., Li, Y., Mitts, N. G., \& Wright, L. (2017). Effectiveness of career choice interventions: a meta-analytic replication and extension. Journal of Vocational Behavior, 100, 175-184. http://dx.doi.org/10.1016/j.jvb.2017.03.010

Received: March 19, 2019

Final version: January 17, 2020

Approved: March 19, 2020 